\title{
قراعة في كتاب \\ منهج البحث الاجتماعي بين الوضعية والمعيارية. \\ تأليف: محمد محمد امزيان
}

\section{دعاء عحمود فينو}

هذا الكتاب في أصله، دراسة قدمها الباحث لنيل درجة الدكتوراه من قسم الفلسفة

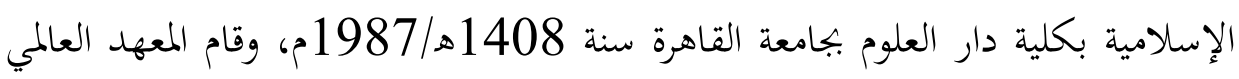
للفكر الإسلامي بتقديمه للمثقف العربي المسلم في عام 1991م، ضمن سلسلة الرسائل الجامعية.

يعرض المؤلف للمساجلة القائمة بين المنهجين المتقابلين في العلوم الاجتماعية،

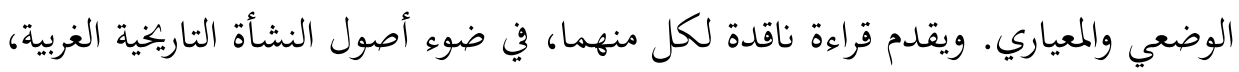

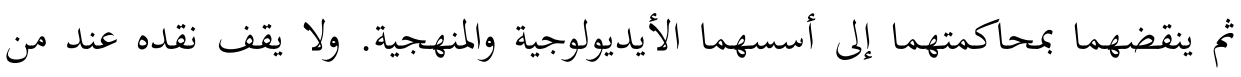
يمثل هذين المنهجين من الغربيين ، بل هو يطال كذلك، ممثليهما في الوطن العربي،

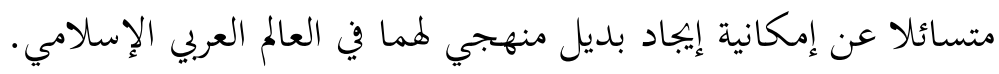

وهو لا يكتفي بالنقد والتساؤل، بل نجده مؤيداً، لأي جهد يعرض مشروع علم

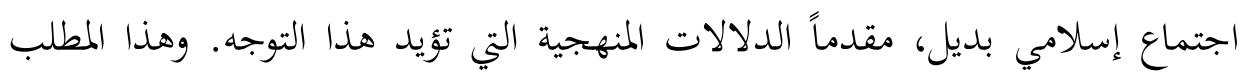

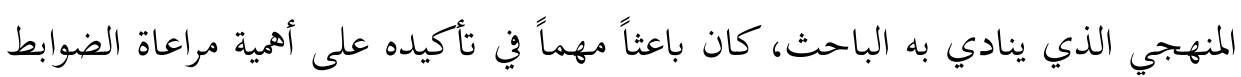

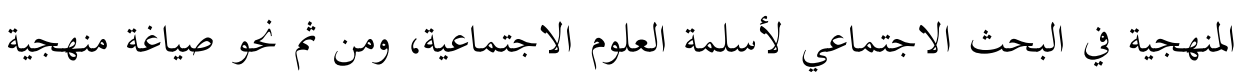
لدراسة التراث الاجتماعي في الإسلام.

* امزيان، محمد محمد. منهج البحث الاجتماعي بين الوضعية والمعيارية، فيرجينيا: المعهد العالمي للفكر الإسلامي، ** دكتوراه في الدراسات الإسلامية من جامعة بيرمنجهام- بريطانيا. 2004 م، عضو هيئة تدريس في كلية تدريب

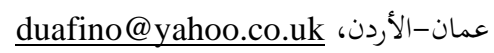


ولعل هذه المقدمة المختصرة التي بدأنا بها مراجعتنا، تثير لدى مثقفينا أسئلة معرفية

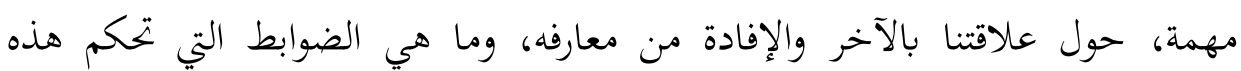

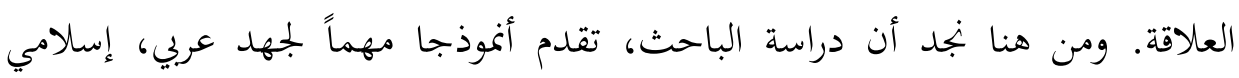

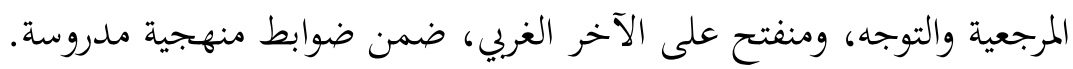

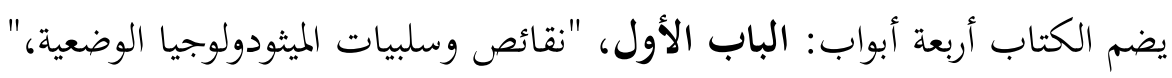

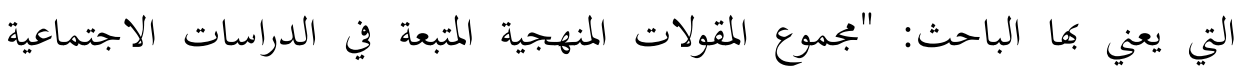

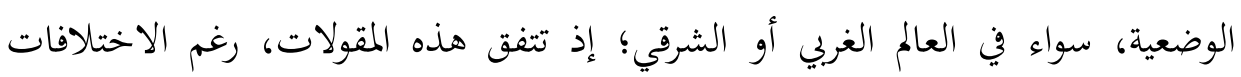

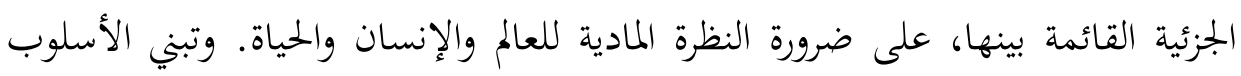

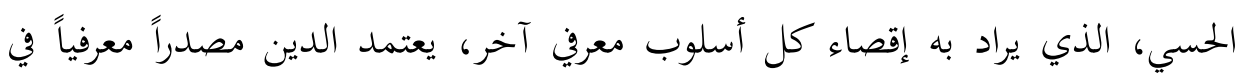

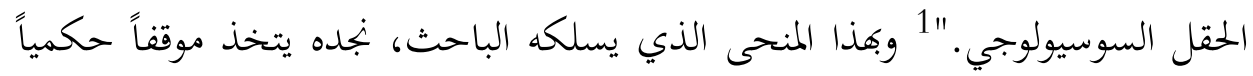

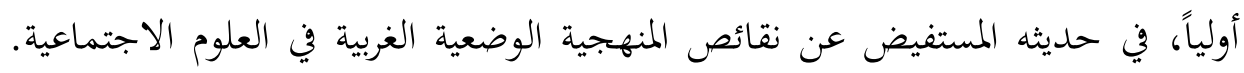

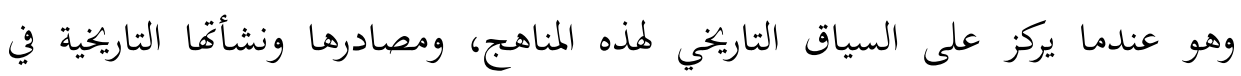

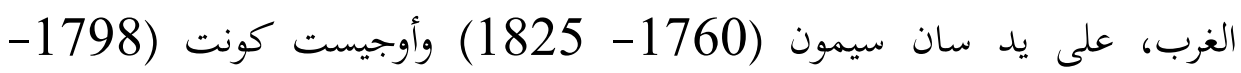

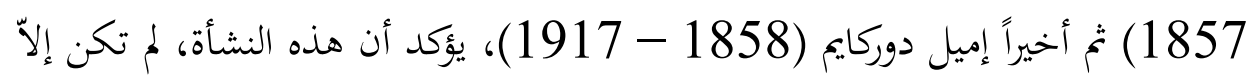

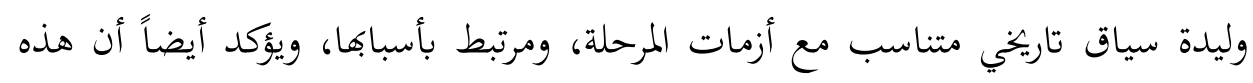

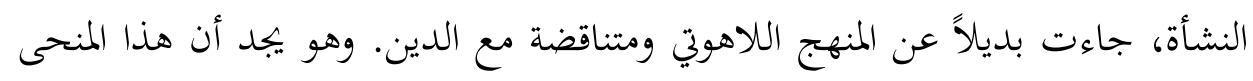

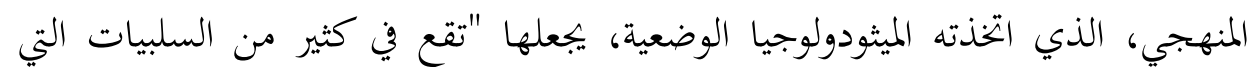

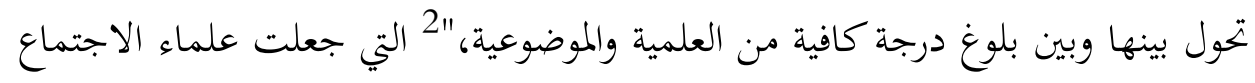
لاحقا "كَهَنَةَ الدين الجلديد."

ويهدف الباحث من خلال عرض سلبيات هذه المنهجية الوضعية، إلى ضبط هذه

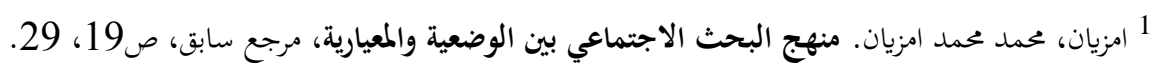

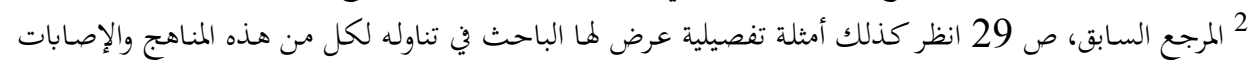

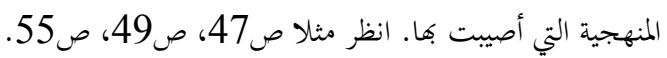
3 المرجع السابق،، ص61 التصني 


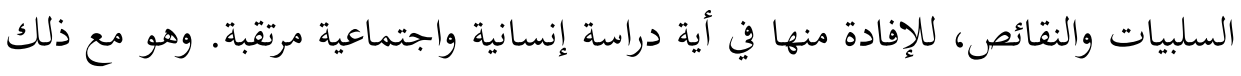

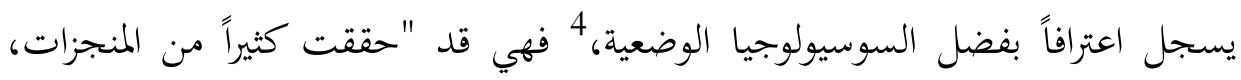

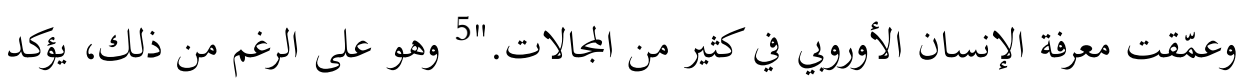

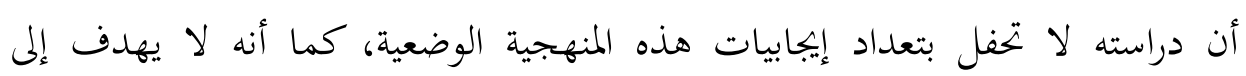

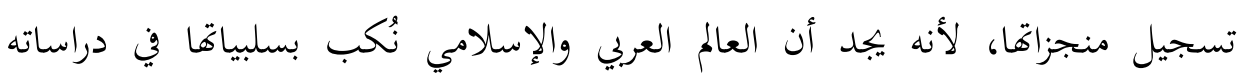

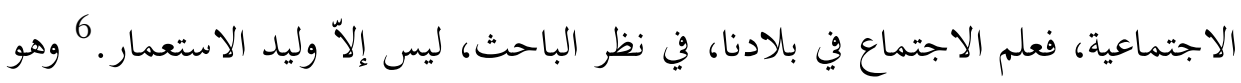

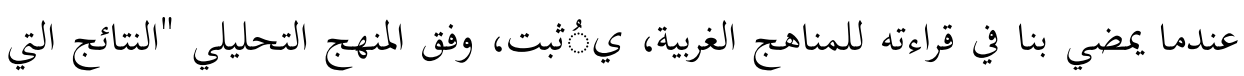

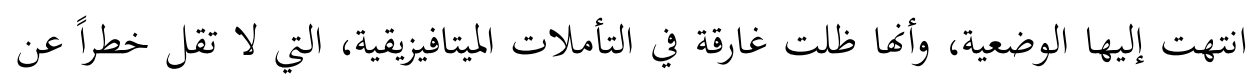

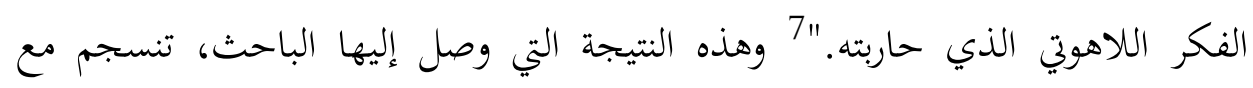

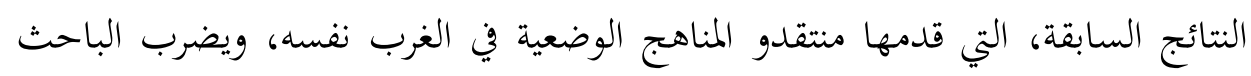

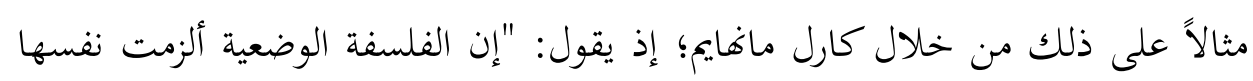

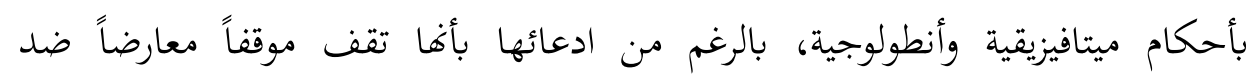

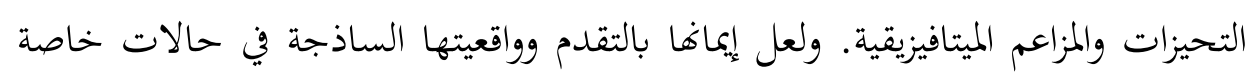
أمثلة على تلك الأحكام الأنطولوجية."

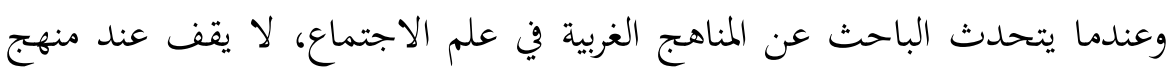

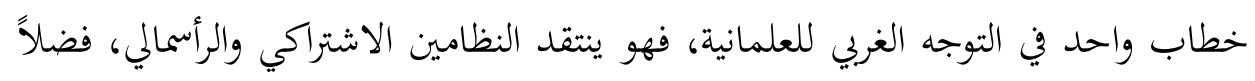

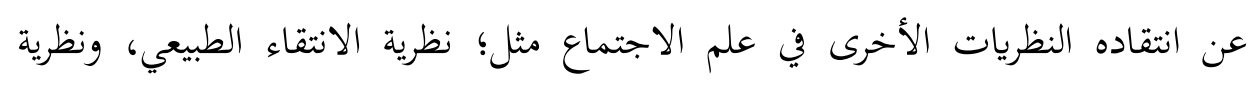

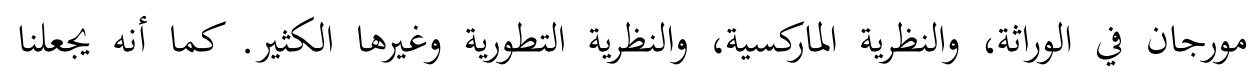
نتلمس التناقضات بينها، فكل منها تنقض الأخرى، مبدية نقائصها المنهجية، أو تتجاوزها

$$
\begin{aligned}
& 4 \text { المرجع السابق،، ص61. } \\
& 5 \text { المرجع السابق،، ص29. } \\
& 6 \text { المرجع السابق،، ص30. }
\end{aligned}
$$

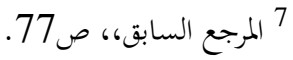

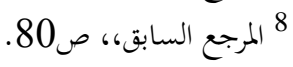


مضيفة لها لتعلن التفوق عليها. 9 ولعل أسباب صراع هذه المناهج، كما يلخصها لنا الباحث، تتمحور حول انعدام إطار مرجعي موحد، والاقتصار على التفسير الأحادي، والتضخم المذهبي. وفي ضوء ذلك يُهبر الباحث النقيصة الكبرى لعلم الاجتماع الغربي، وهي ماثلة في خضوعه لخدمة الأهداف الاستعمارية. ويشكل هذا المبعطى النظري لمنتج علم

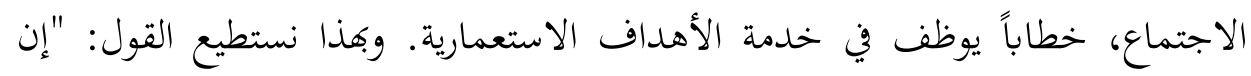
الأهداف الأيديولوجية من أخطر العقبات التي تعترض طريق علم الاجتماع، ومن أخطر

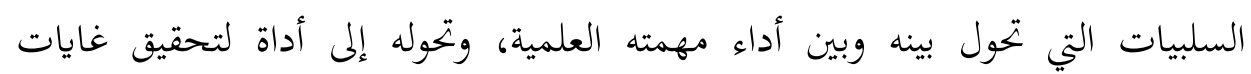

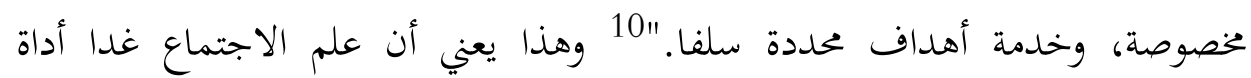

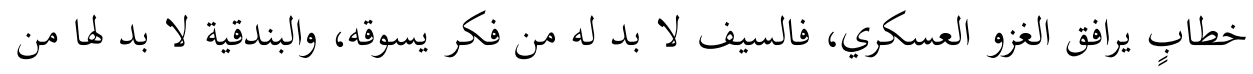

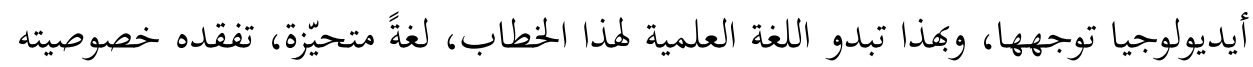

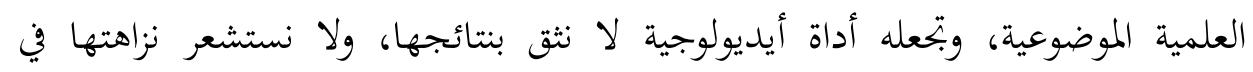

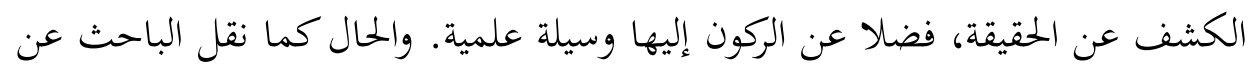

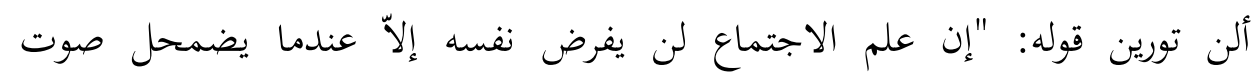
الأيديولوجيا السائدة، وفيما عدا ذلك يظل مضايقاً ومنفياً."

أما الباب الثالي، فيتحدث فيه الباحث عن "تمثيل المدارس الاجتماعية في الوطن

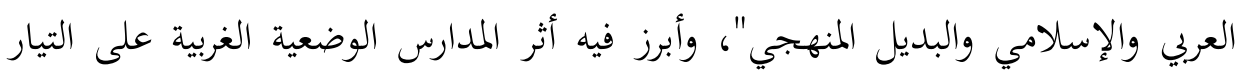

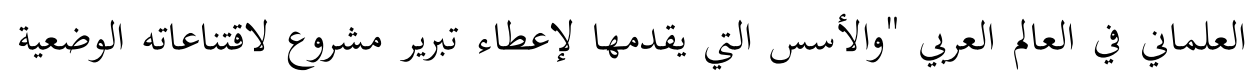

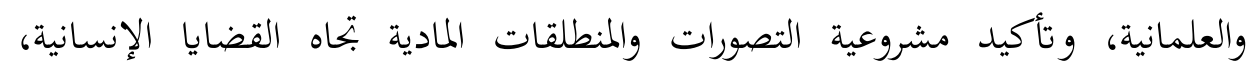
والمشكلات الاجتماعية."12 كما أظهر الباحث هذا الأثر جلياً، في محاكاة التيار العلماني

$$
11 \text { } 11 \text { المرجع المابق، المرجع صالسابق،، ص129 ا129.129. } 129
$$


العربي لنظيره الغربي، في مناوأة كل ما يتصل بالدين. ويرى الباحث أن التيار العلماني

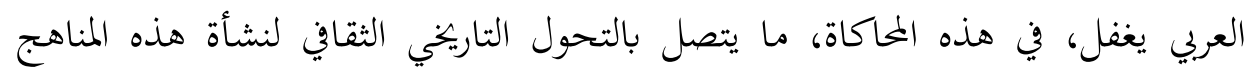

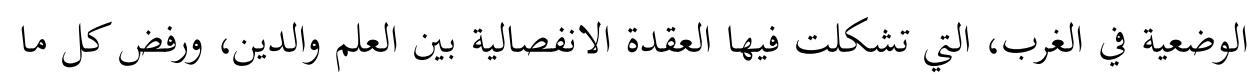

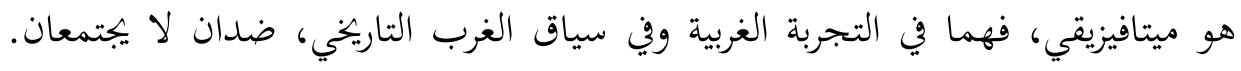

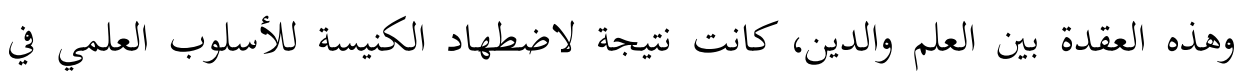

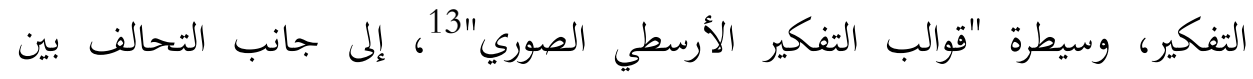

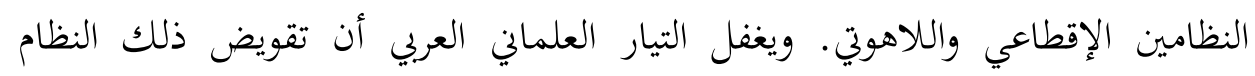

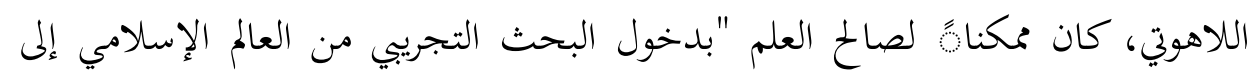

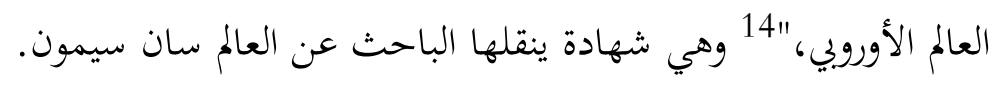

وقد عرض الباحث تحليلاً عميقاً لتلك الأسس التي اعتمدها العلمانيون، وبيَّن كيف

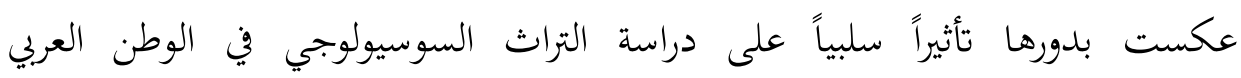

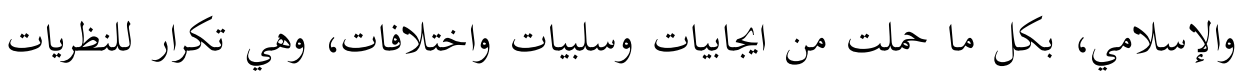

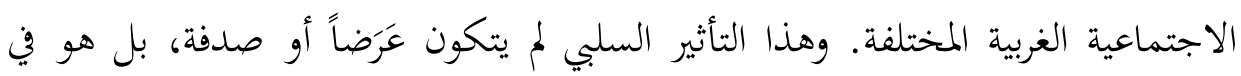

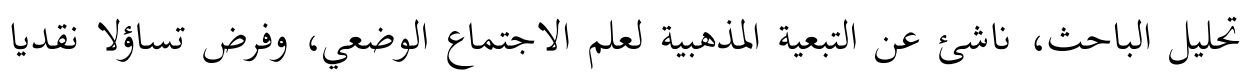

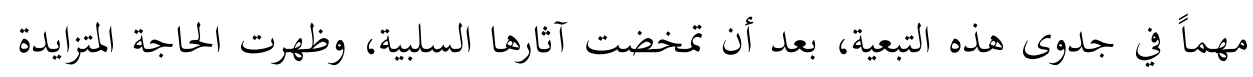
لمناهج اجتماعية بديلة لتلك الوضعية، التي ينبغي أن تكون أصيلة المنشأ والانتماء. ولإيجاد هذا البديل تمحورت هذه الجهود في ابحاهين. وهذان الاتحاهان - في قراءة

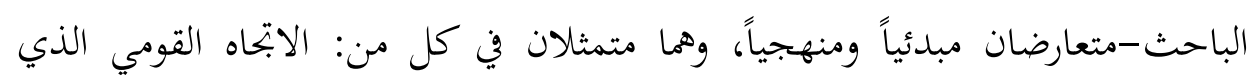

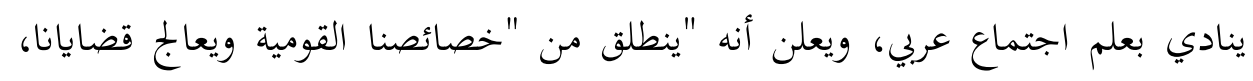

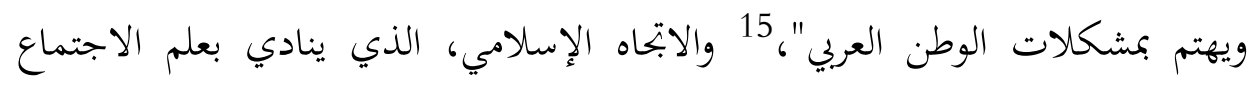
الإسلامي، الذي تمتد جذوره العقدية في الأساس التشكيلي للأمة على مدى الإسلى قرون.

$$
\begin{aligned}
& \text { المرجع السابق،، ص34. } \\
& 14 \text { المرجع السابق،، ص37. لرجات، ص37. } \\
& 15 \text { المرجع السابق،، ص21. }
\end{aligned}
$$


ويعرض نفسه "إطاراً أيديولوجياً عقائدياً في مقابل الأيديولوجيتين الرأسمالية والماركسية."16 ويجد الباحث أن العودة إلى الذات العربية، بوصفها مرجعية يلتزم بها، قد تصدم

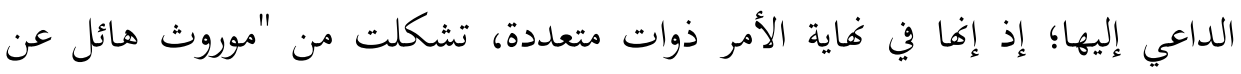

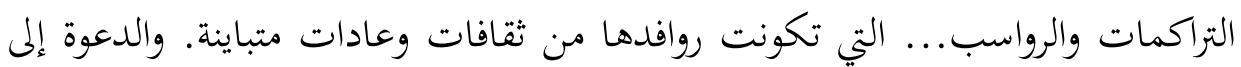

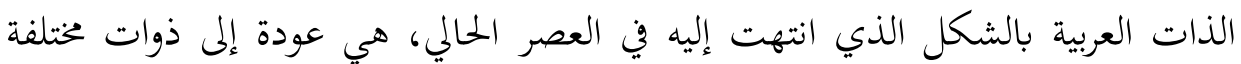
ومتعددة بحسب الخلفيات العقائدية، التي انتهت إليها القومية العربية، والتي جعلت منها

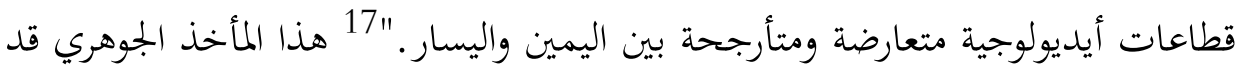
يضاف إليه، كما يرى الباحث، تساؤل "يتمركز عما إذا كانت القومية- أية قومية-

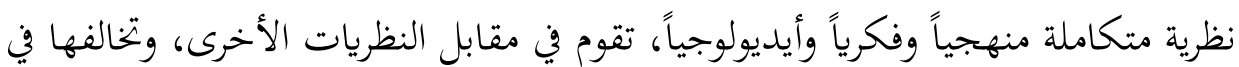

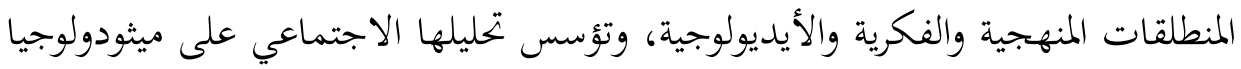
مستقلة."18

والحقيقة، أن النقد المركزي الذي يوجهه الباحث للقراءة الاجتماعية للتراث العربي،

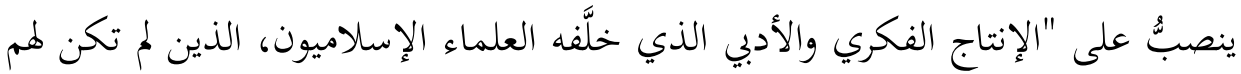

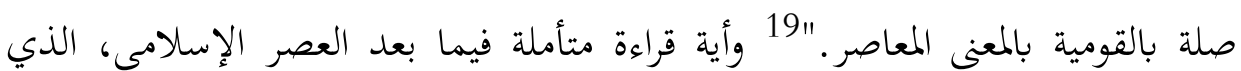
عاشته الأمة العربية، يجب أن يُنَقَّب عنها "في مجموع الثقافات التي استوردتها القومية التي تقوّضض الثقافة الإسلامية داخل المجتمع العربي، تلك الثقافة المضادة التي فرضوها على هذا

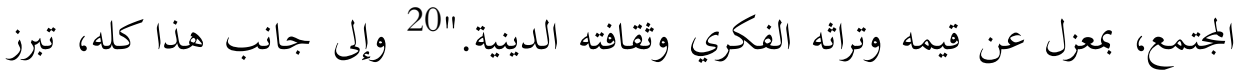

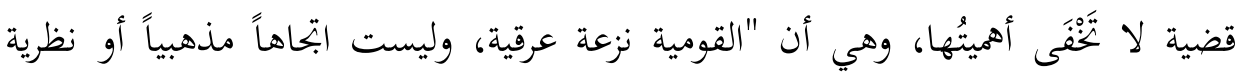

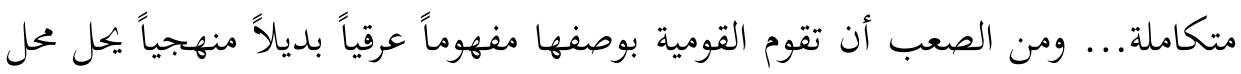

$$
17 \text { } 16 \text { } 16 \text { المرجع المرابق، المرجع المابق، ص212. }
$$




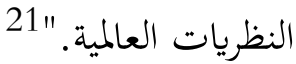

ثم يمضي الباحث قائلاً: "إننا نؤكد -ومع إصرار - أن الذي يعطي لعلم الاجتماع

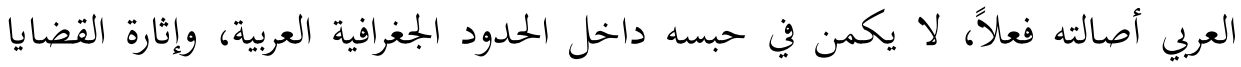

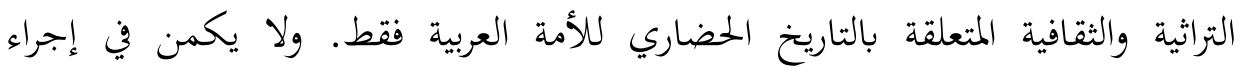
المفاضلات بين مناهج الشرق والغرب، واختيار نموذج دون آخر حسب الغربه ما تمليه الأهداف القومية. إن الذي يضمن أصالة قيام علم اجتماع عربي فعلاً، هو مدى إنى ارتباطه

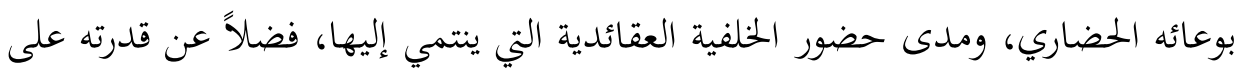
تجسيد أصالته، التي بمقدورها مواجهة الزيف العقائدي الذي تمارسه النظريات الوضعية،

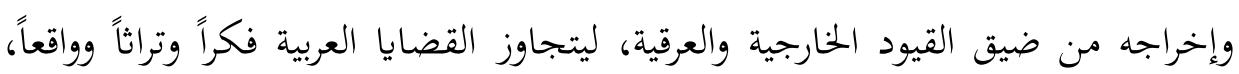

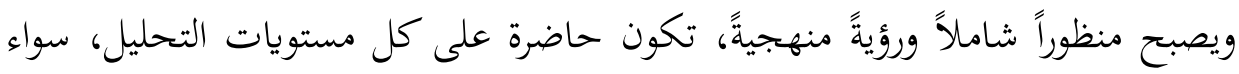

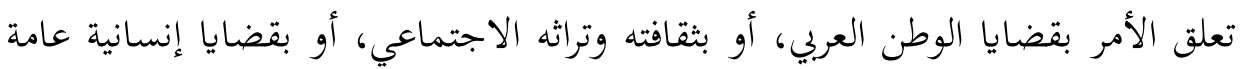
تتجاوز هذه الحدود وهذه الثقافة.

إن هذه المهمة الصعبة، هي التي ينتظر أن يقوم بها علم الاجتماع الإسلامي، بوصفه

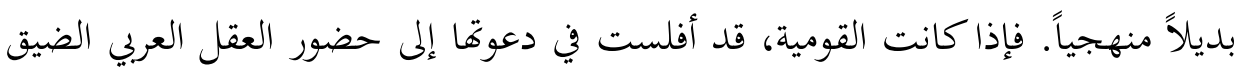
على المستوى النظري والمنهجي والجغرافي، فإننا ندعو إلى حضور العقل الإسلامي بتصوره

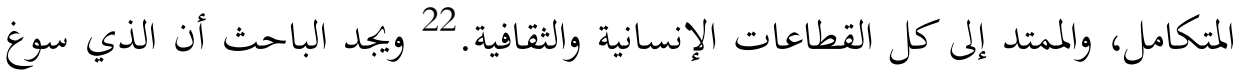

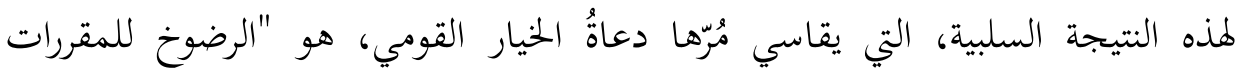

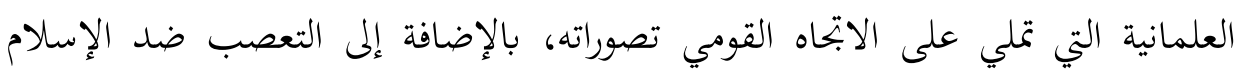
ومذهبيته. "23

هذا الموقف المنهجي المفصلي، من البديل القومي، الذي يقف عنده الباحث في

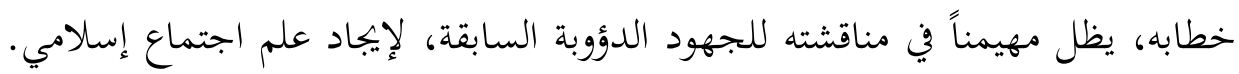

$$
22 \text { } 22 \text { المرجع السابق،، ص220. }
$$


فهو بطموحه إلى علم اجتماع إسلامي، لاَ يسقُط تابعاً للنظريات الغربية من جانب، أو أو أبرات

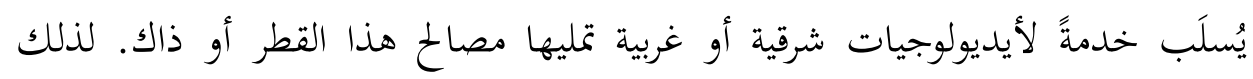

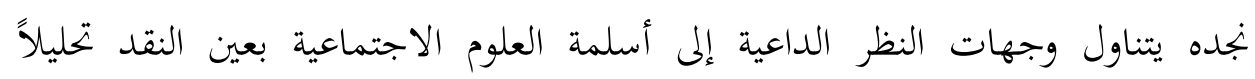

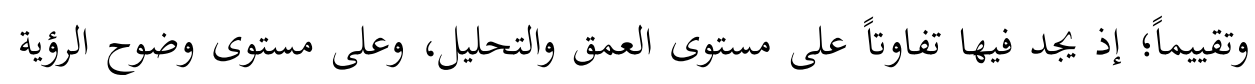

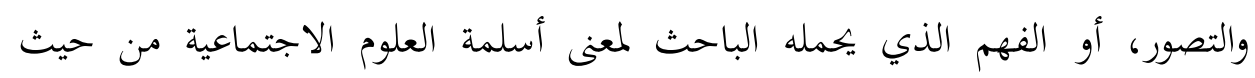

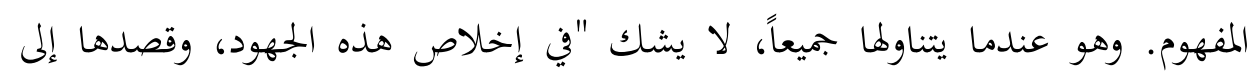

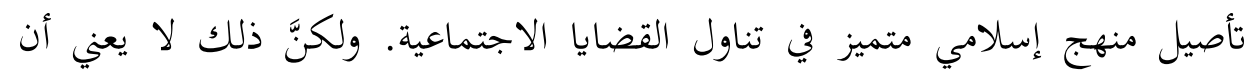

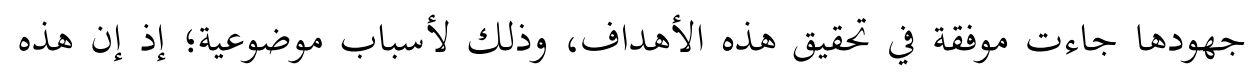

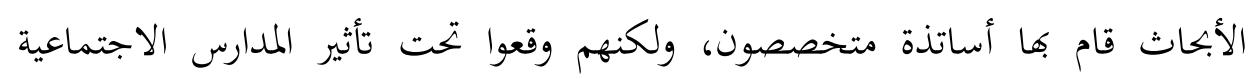

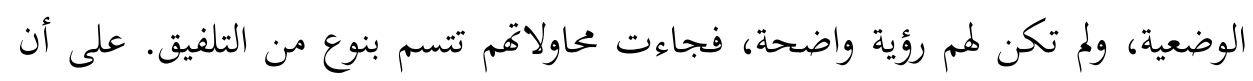

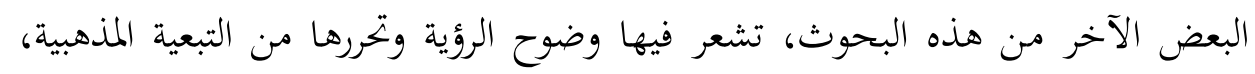

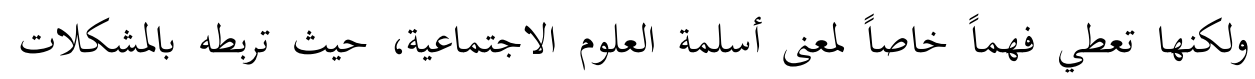
المرتبطة بالتراث والثقافة والمخيط الإسلامي.

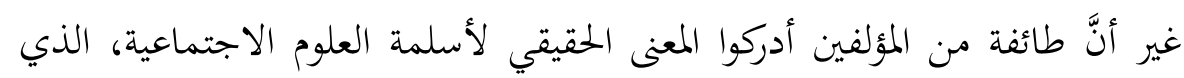

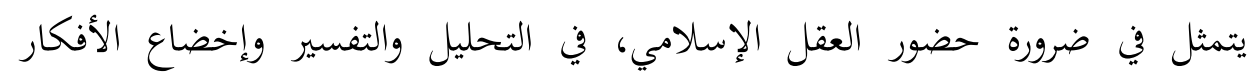

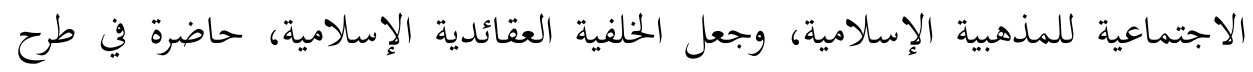

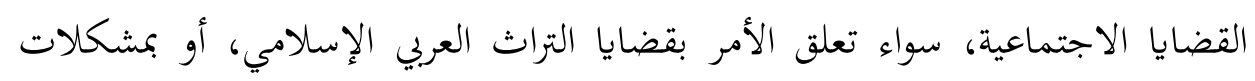

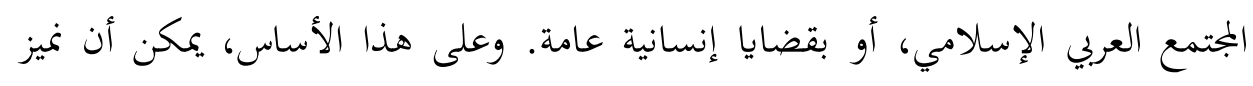

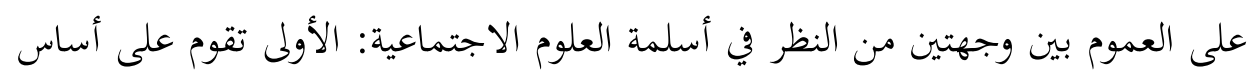

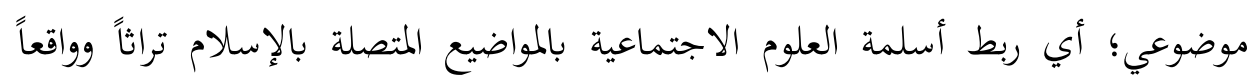
وفكراً، والثانية تقوم على أساس منهجي عقائدي؛ ألى ألي ربط أسلمة العلوم الاجتماعية

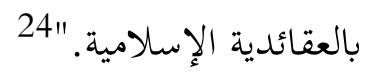

$$
\text { 24 - 24 - مرجع السابق،، ص227. }
$$




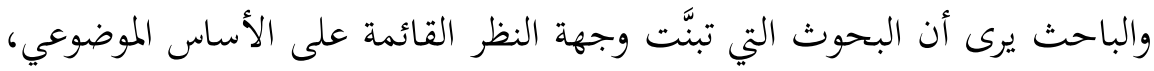

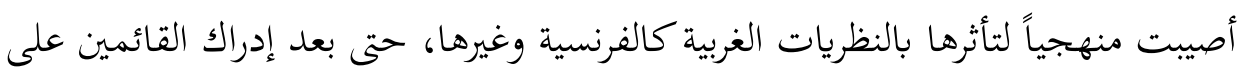

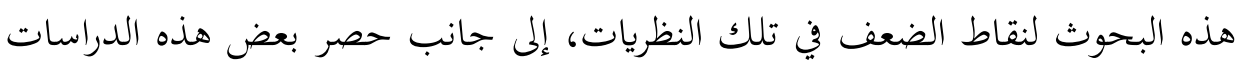

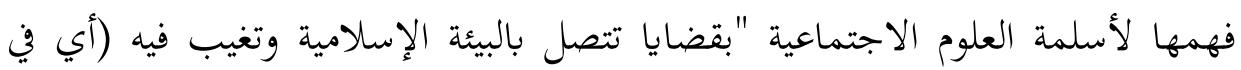

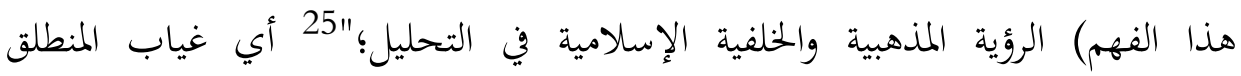

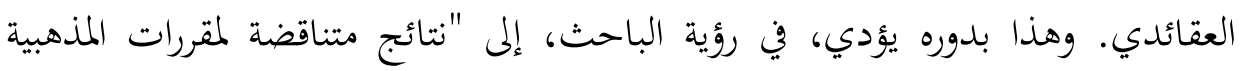

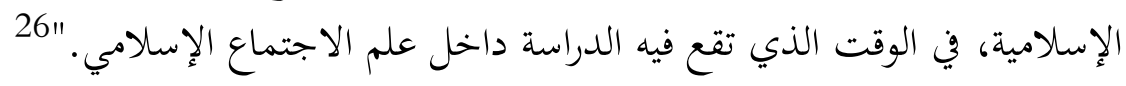

ويمضي الباحث في قراءته للجهود الكثيرة والمتنوعة لوجهة النظر الوضعية، مؤكداً

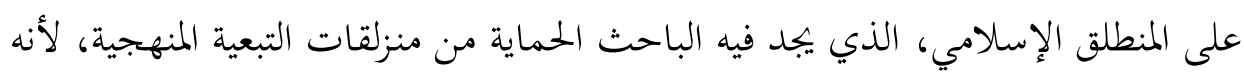

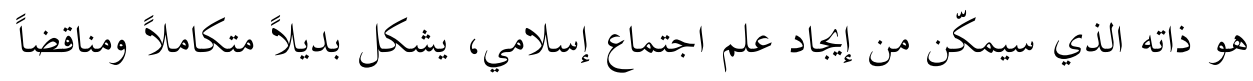

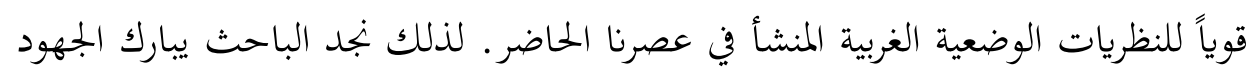

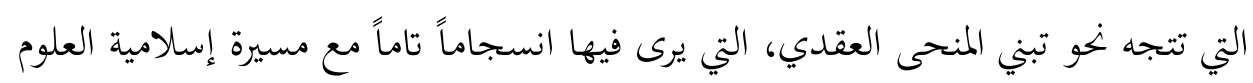

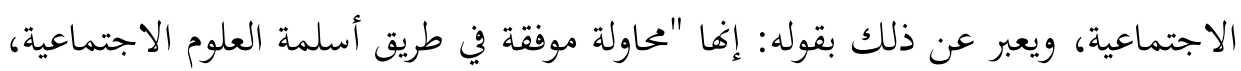

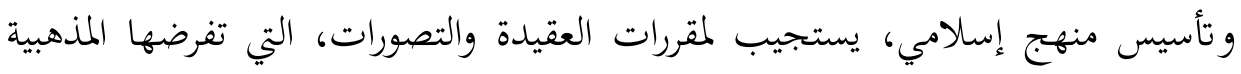

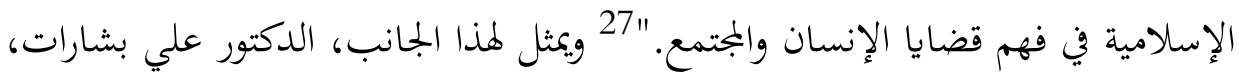

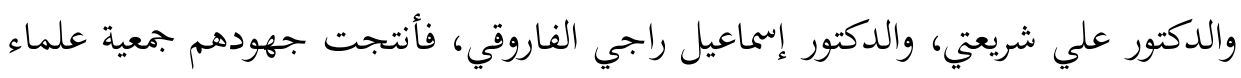

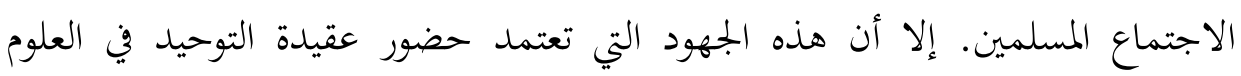

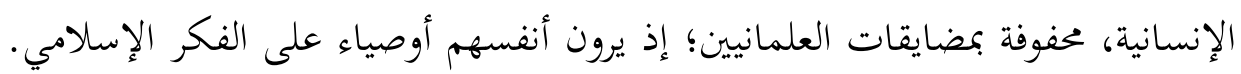

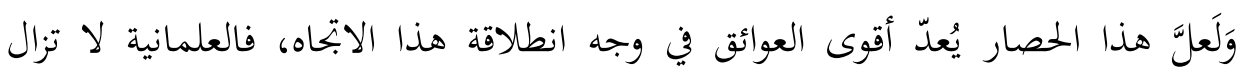

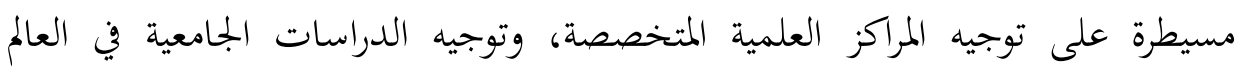

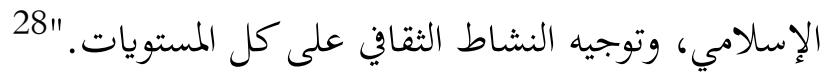

$$
28 \text { المر المرجع السابق،، ص229 المرجع السابق، ص237. }
$$


ولعل مما يؤكد غياب الوعي في الأمة الإسلامية، بتحاه هذا الخطر الذي يهيمن عليها،

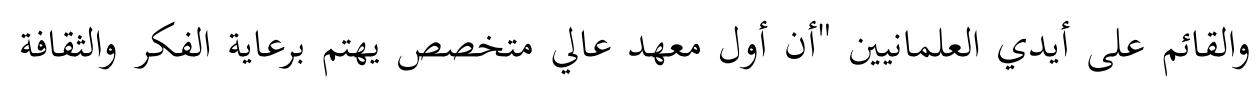

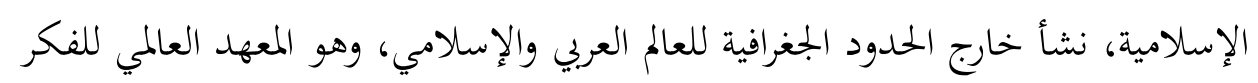

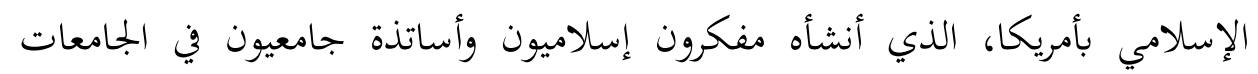

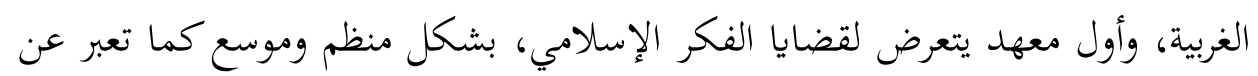

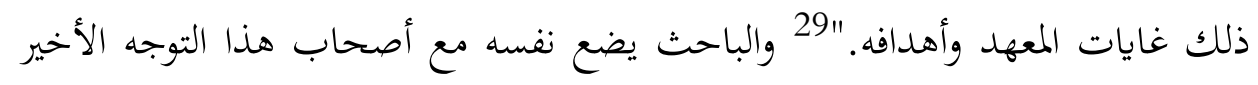

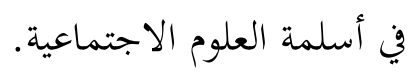

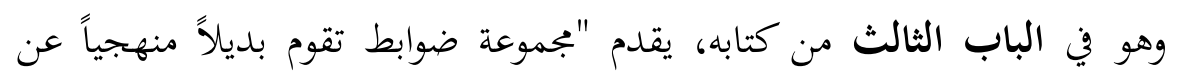

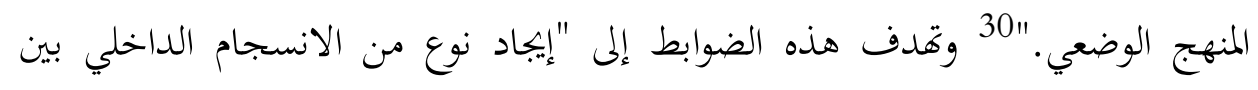

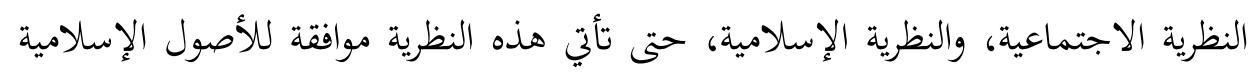

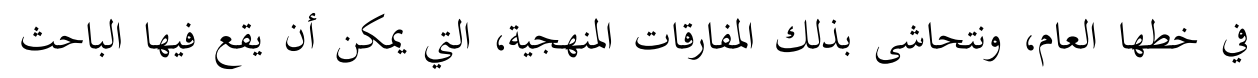

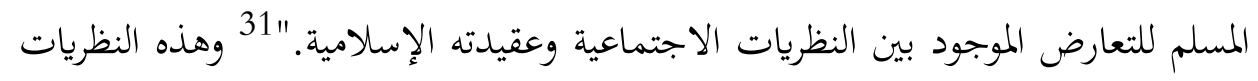

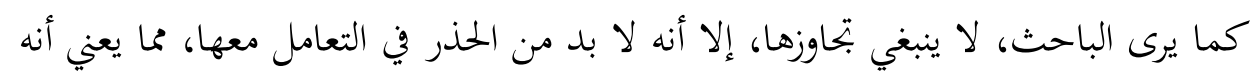

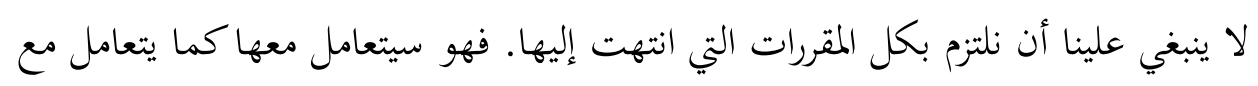

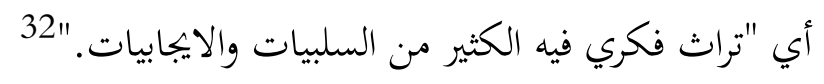

ويتحدث الباحث عن هذه الضوابط قائلاً بأها "ليست سوى مجموعة من المؤشرات

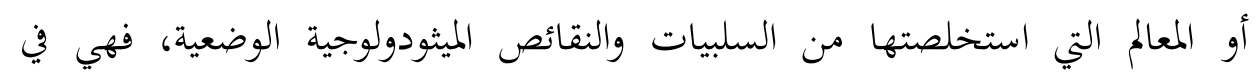

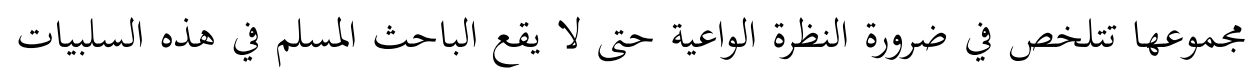

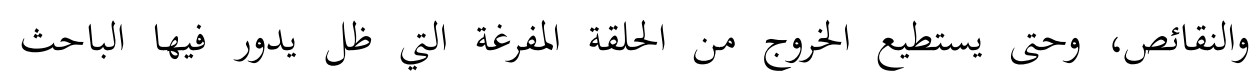

\begin{tabular}{|c|}
\hline 29 2لمرجع السابق،، ص242. \\
\hline 30 المرجع السابق، ص244. \\
\hline 31 المرجع السابق، ص247. \\
\hline 32 المرجع السابق، ص247. \\
\hline
\end{tabular}


الاجتماعي في عالمنا الإسلامي، لالتزامه بالقوالب الشكلية للنظريات الوضعية."33 ويرى

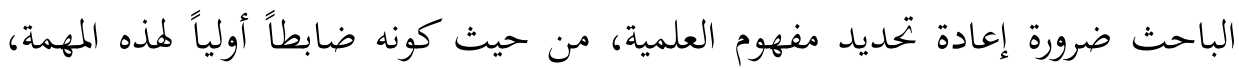
مذكراً بأن النظرة التي وجهت لمفهوم العلمية، كانت "تكمن في التخلص من من كل تفكير العيد

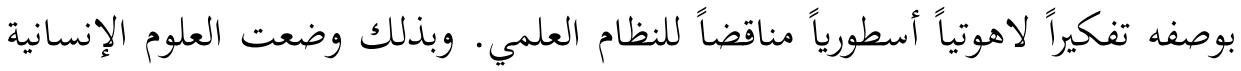
أمام الخيار الصعب، بحيث فئرض نفرض عليها النموذج الطبيعي، بوصفه طريقاً وحيداً

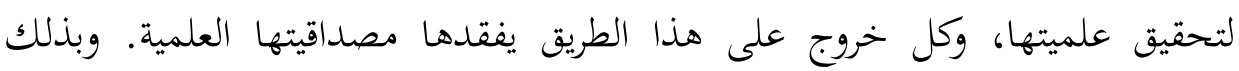
تحولت النزعة العلمية من أسلوب في البحث، إلى اعتقاد في العلم التجريبي، بوصفه طريقاً

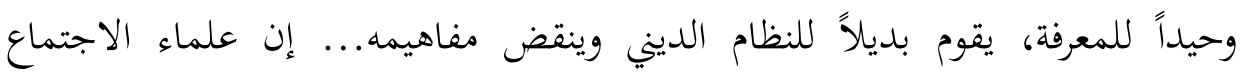
بسلوكهم هذا المسلك المتطرف، يفترضون أن الموضوعات التي يدرسوها، لها طبيعة مادية، ويفترضون أفراداً عديمي الإرادة، يخضعون لجبرية القوانين الاجتماعية التي تقابل القوانين

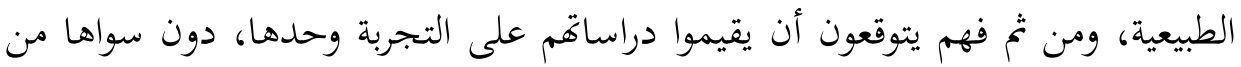

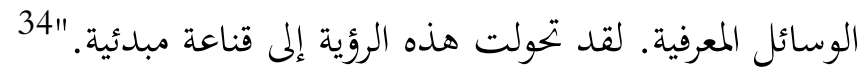

ويرى الباحث أن هنالك فوارق موضوعية ومنهجية بين العلوم الطبيعية والعلوم

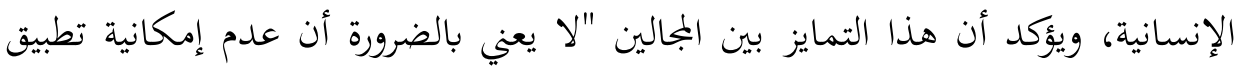

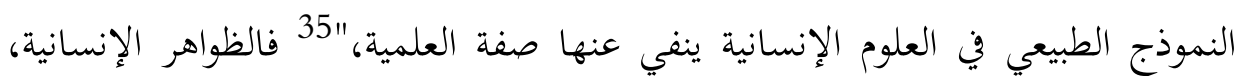
ليست في واقعها مظاهر حسية، تخضع للملاحظة أو غيرها من الوسائل التجريبية.

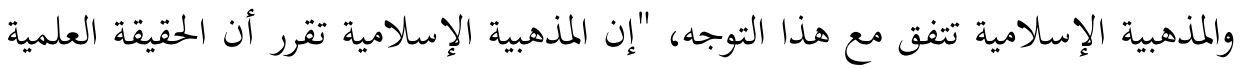
ليست حكراً على التجربة، وأن الوجود الواقعي ليس حكراً على الوجود المادي، وأن التزام

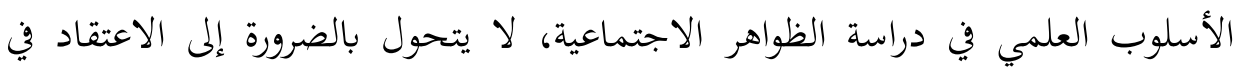

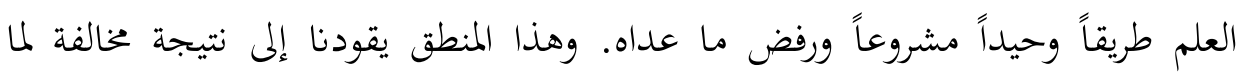
انتهت إليه الميثودولوجيا الوضعية، وهي أنه ليس من الضروري أن يكون هناك نوع ورون واحد 
من العلم، وبالتالي فليس من الضروري أن نتحدث عن شكل واحد من أشكال

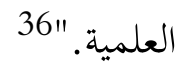

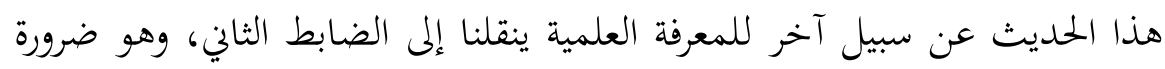

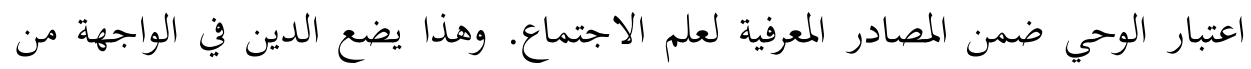

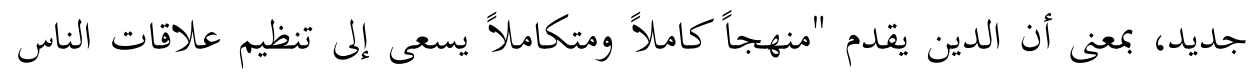

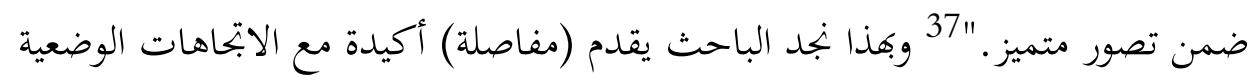

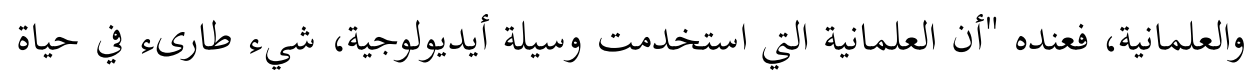

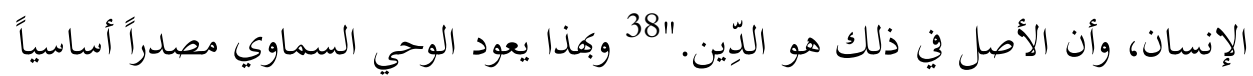

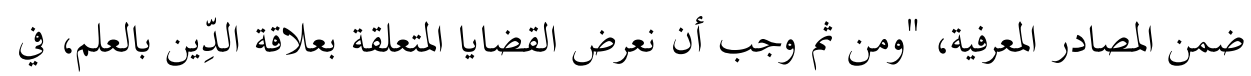

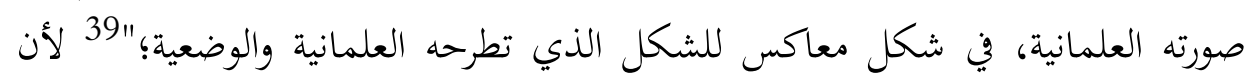

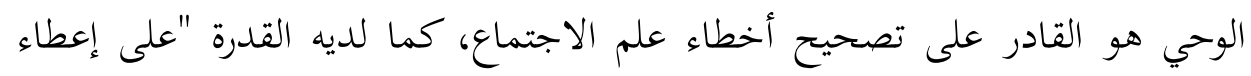

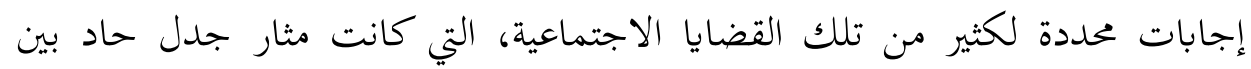

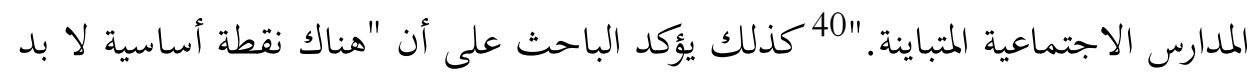

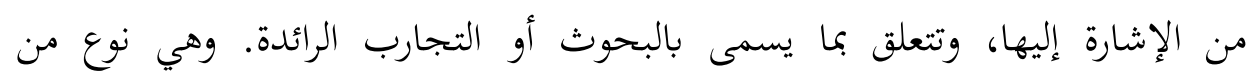

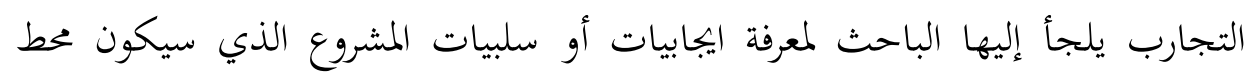

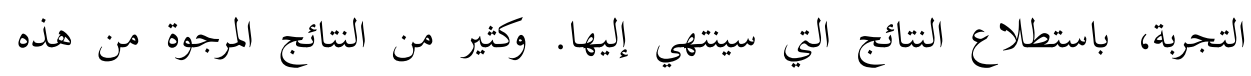

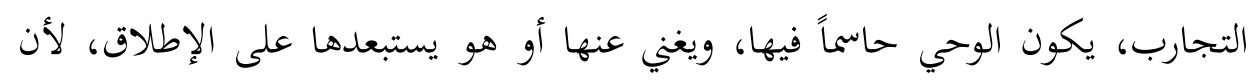

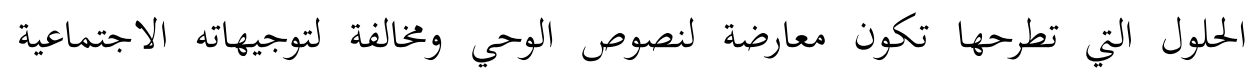
والتربوية، وهي غالبا ما تكون موجهة من قبل العلمانيين."

$$
\begin{aligned}
& 36 \text { المرجع السابق، ص259. } \\
& 37 \text { المرجع السابق، ص265. } \\
& 38 \text { المرجع السابق، ص265. }
\end{aligned}
$$

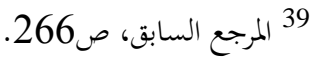

$$
\begin{aligned}
& \text { المرجع السابق، ص267. } \\
& 41 \text { المرجع السابق، ص298. }
\end{aligned}
$$


وإذا كان اعتماد الوحي أساسياً في المعرفة الاجتماعية، فلا يمكن أن يتصور هذا الإدا

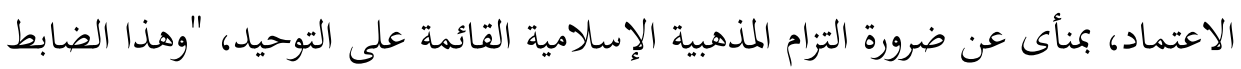

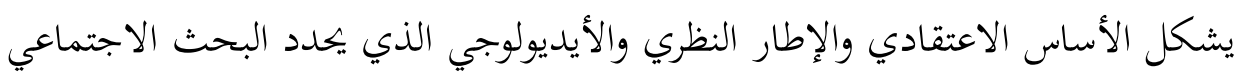

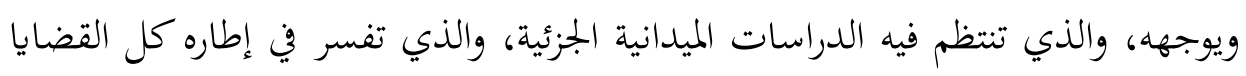

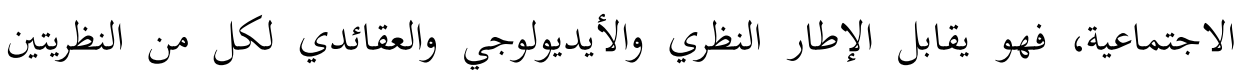

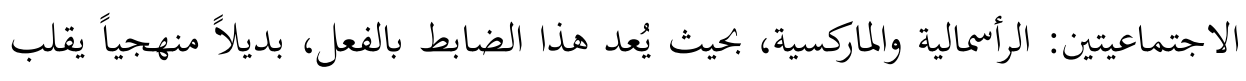

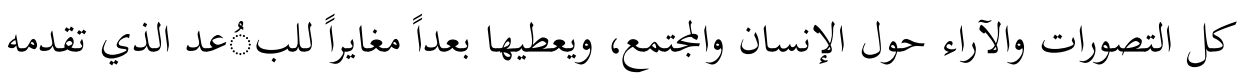

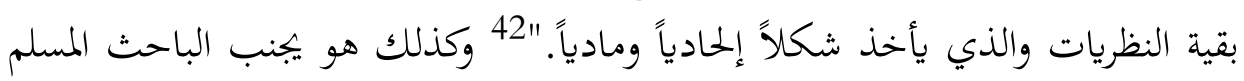

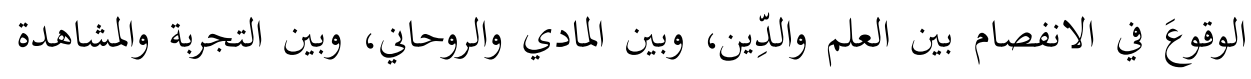

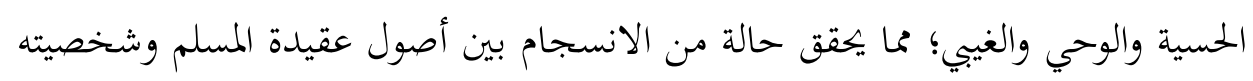
الحضارية.

وبهذا فإن الباحث يحقق مطلباً مهماً في رؤيته الاجتماعية، التي تقوم على التوحيد.

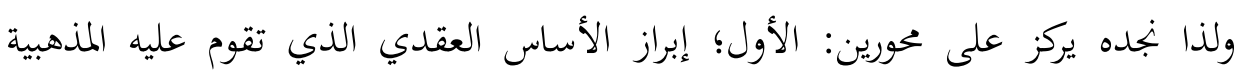

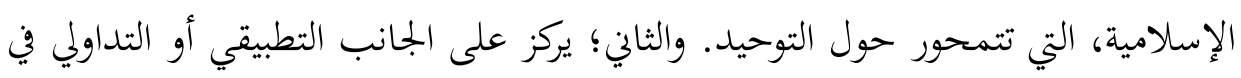

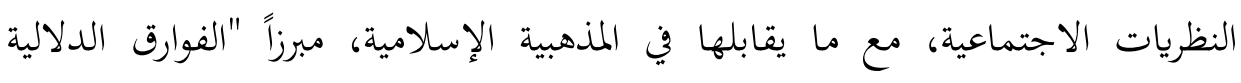

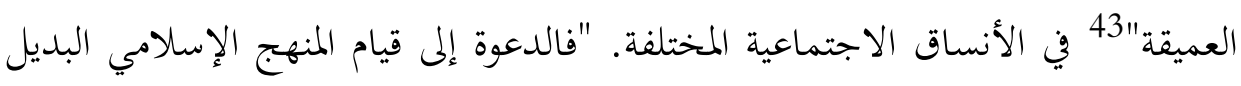

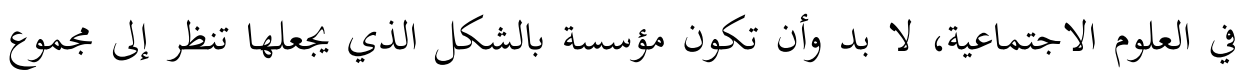

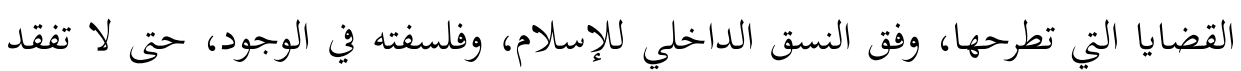

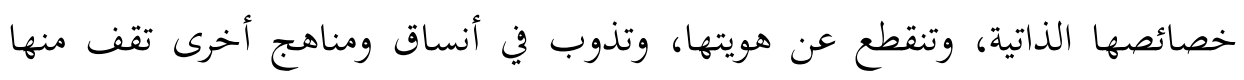

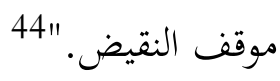

إن الموقف الأساسي الذي نجد الباحث ينافح عنه، هو الحفاظ على الأساس

$$
42 \text { } 43 \text { المرجع السابق، ص301. } 434 .
$$


العقدي في معالجة القضايا الاجتماعية، مع المحافظة على الهوية الذاتية من التأثيرات

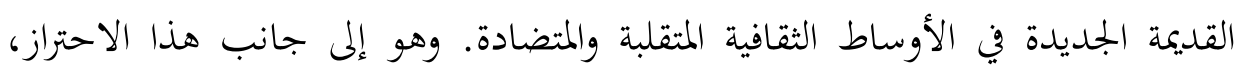

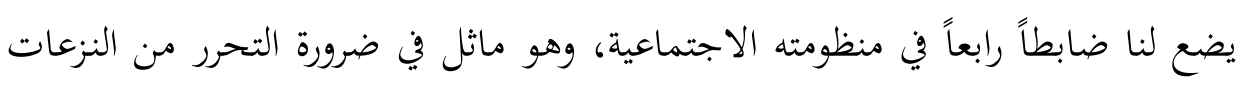

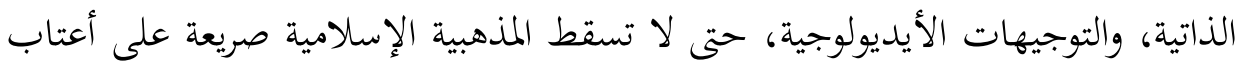

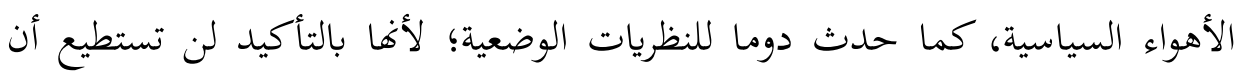

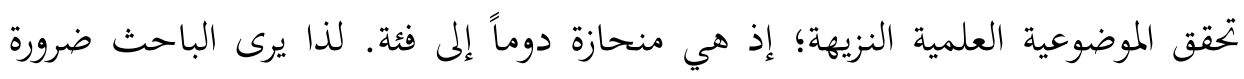

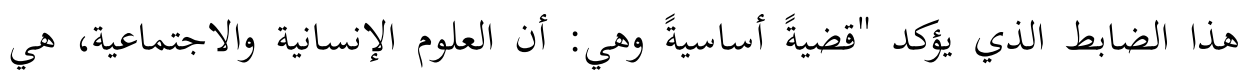

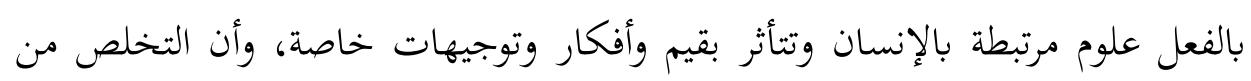

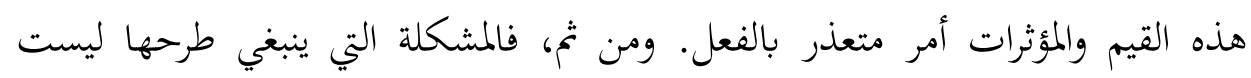

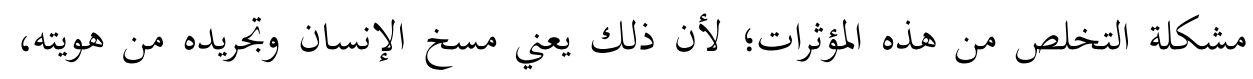

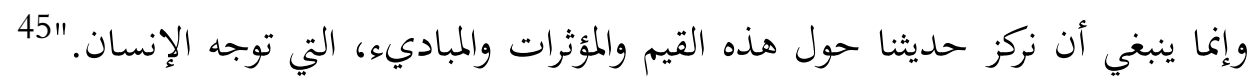

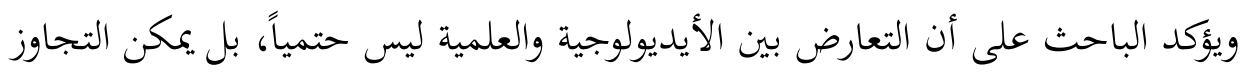

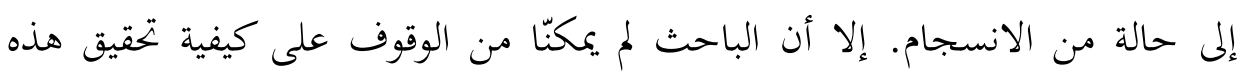

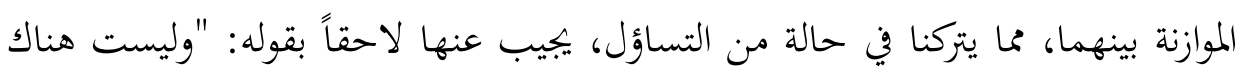

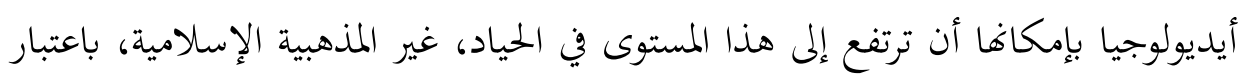

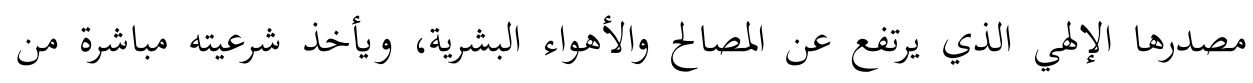

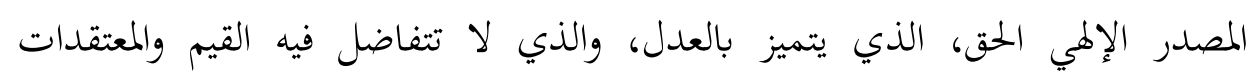

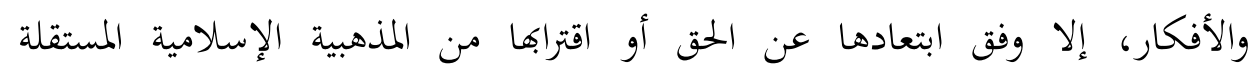

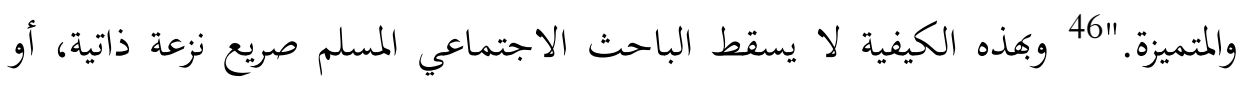

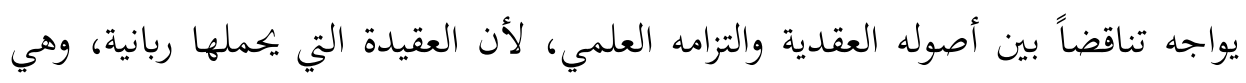
ترفد كل التزام علمي وأخلاقي ودون تحيز إلى فئة.

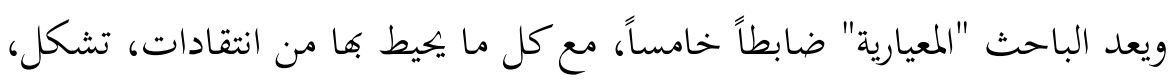

$$
45 \text { 45 } 45 \text { لمرجع السابق، ص326. }
$$




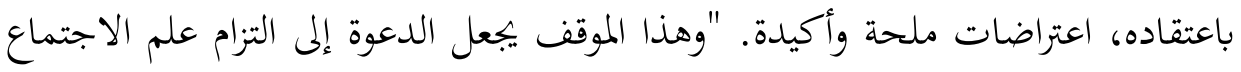

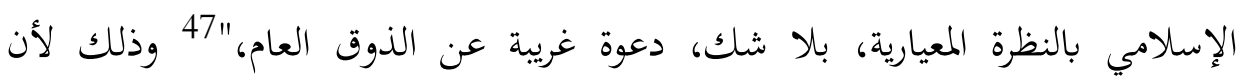

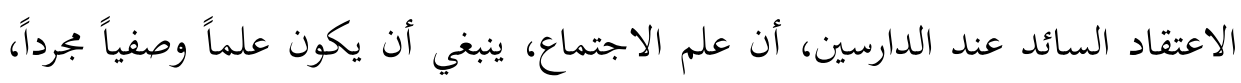

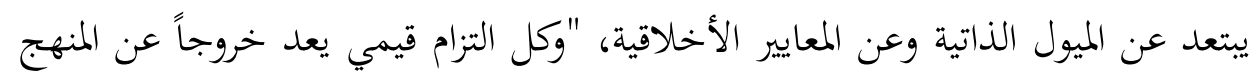

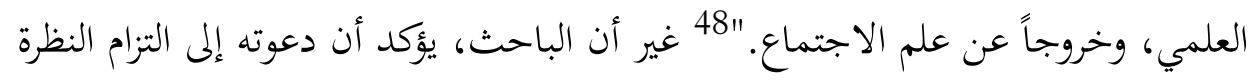

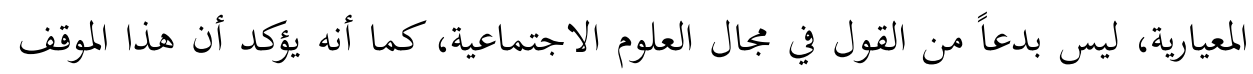

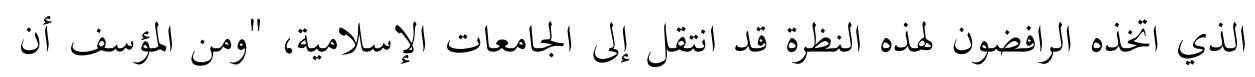

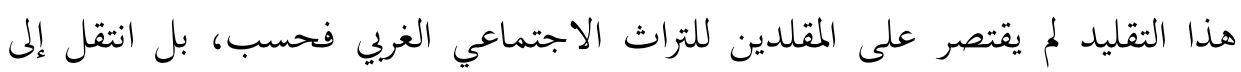

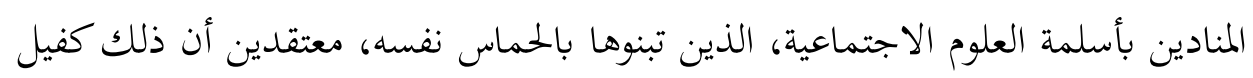

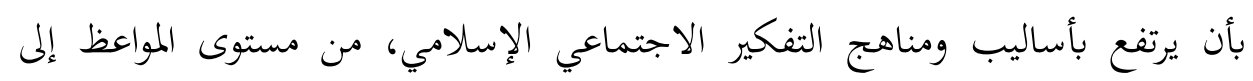

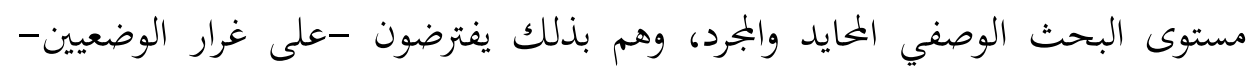
وجود تناقض بين المستويين: مستوى الواقع ومستوى القيم والغايات."

إذن، فالباحث يقدم الالتزام بالنظرة المعيارية، بلا نقائص منهجية تشوبها، مفارقاً

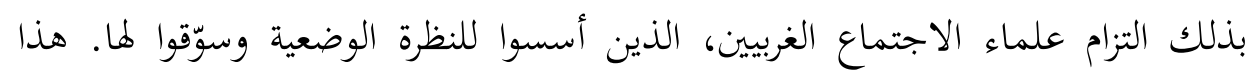

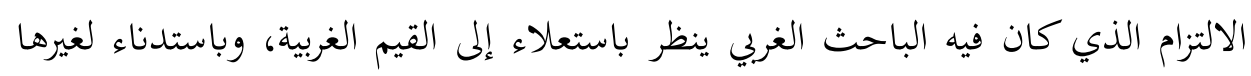

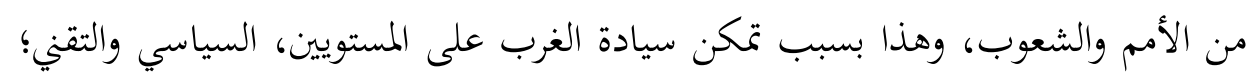

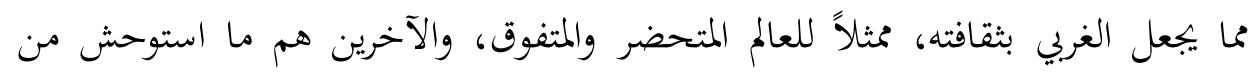

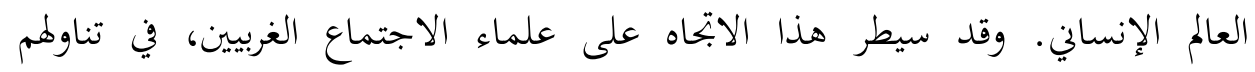

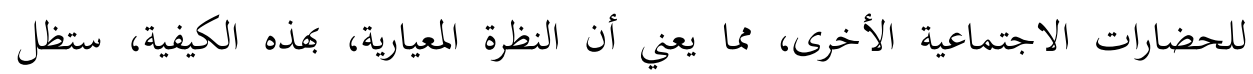
منحازة للغرب فضلاً عن البعد العرقي الإثني العنصري.

ويتساءل الباحث، بعد ذلك، عن دور علماء الاجتماع في تقديم دور إصلاحي في

48 47 48 المرجع السابق، ص335. 


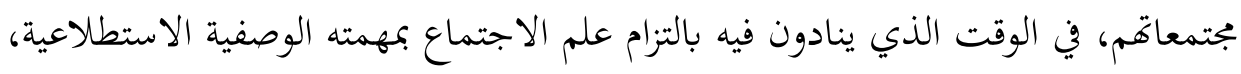

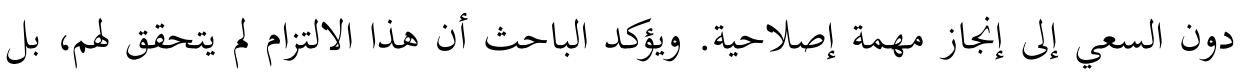

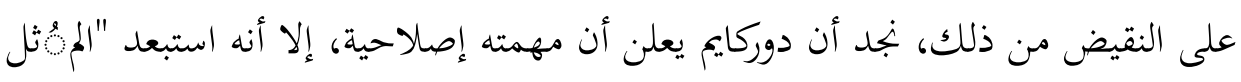
الدينية لتحل محلها المُءثل العلمانية."

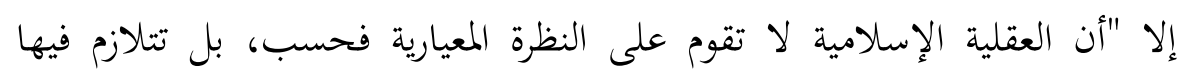

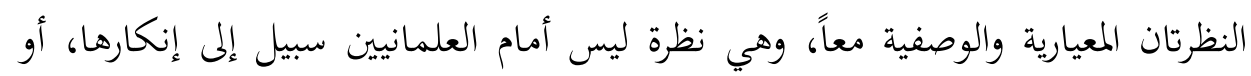

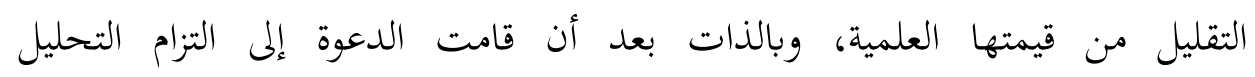

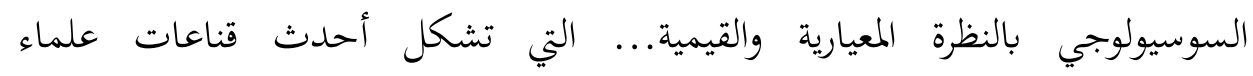

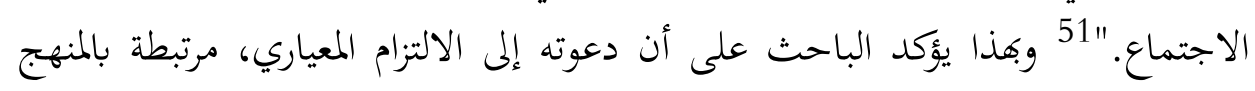

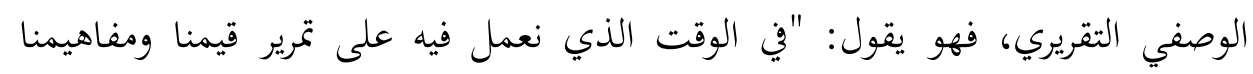

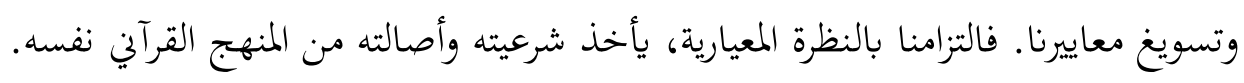
وهو المنهج الذي يؤكد على ضرورة بتحاوز المستوى الوصفي إلى المستوى المعياري."

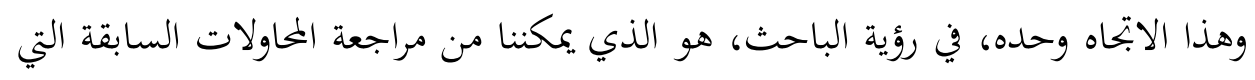

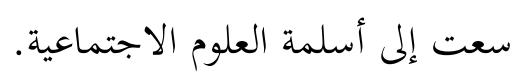

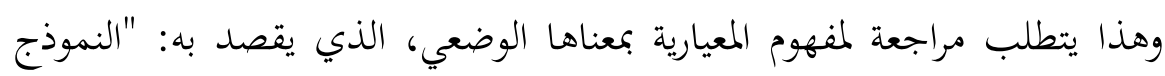

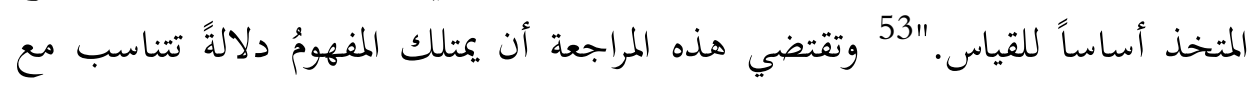

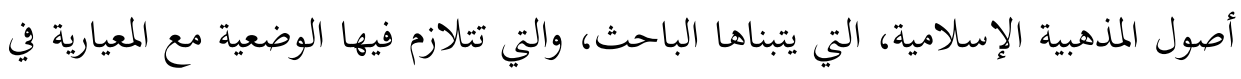

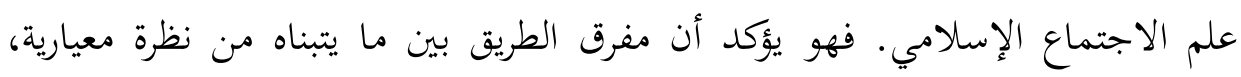

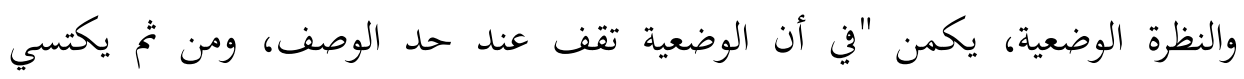

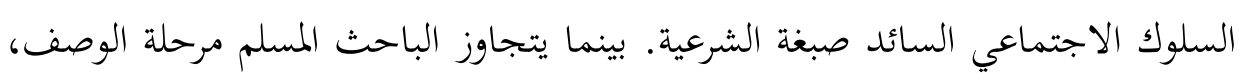

$$
53 \text { } 51 \text { } 51 \text { المرجع السابق، ص339. } 53 \text { المرجع السابق، ص343. }
$$




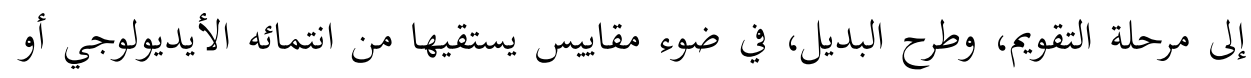

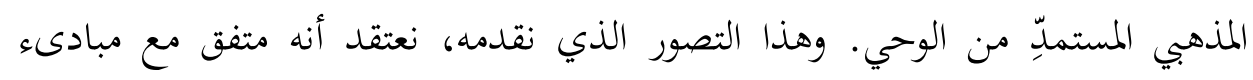

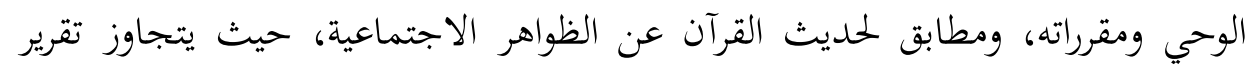

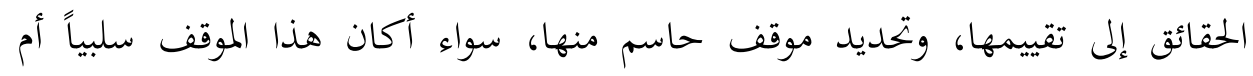

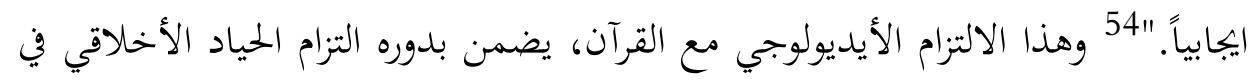
التعامل مع الظاهرة الاجتماعية.

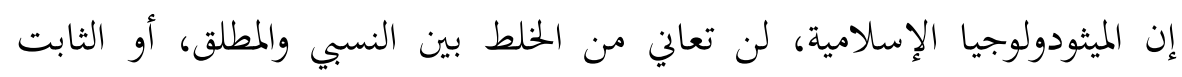

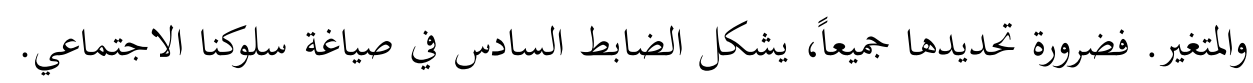

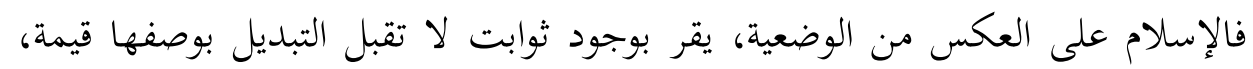

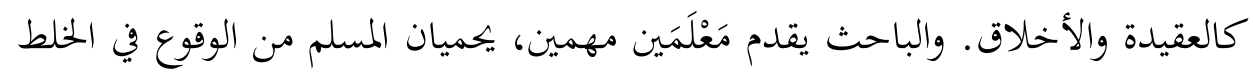

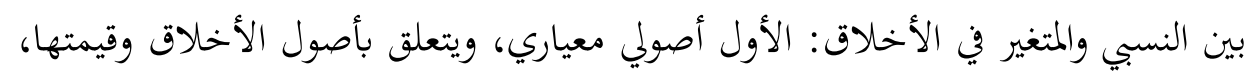

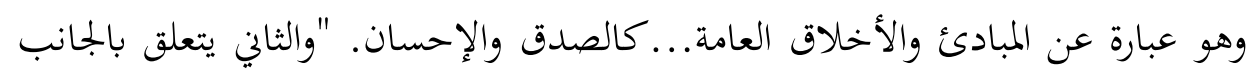

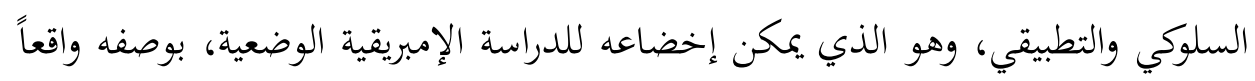

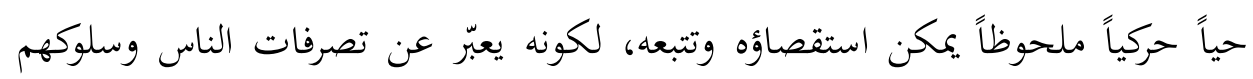
الاجتماعي." أليأ مركباً

ويتمثل الضابط السابع في ضرورة تحاوز التفسير الأحادي، والتزام النظرة الشمولية في

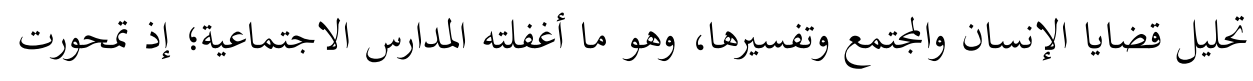

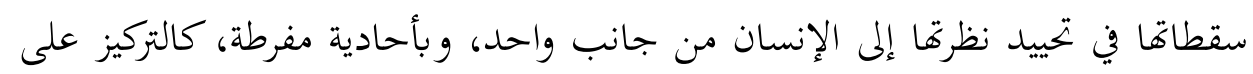

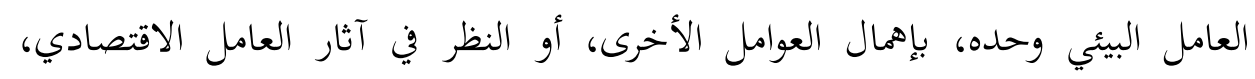

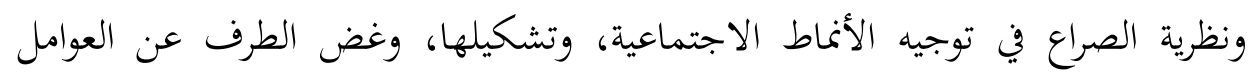

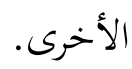

وبهذه الضوابط السبعة، قد يتمكن علماء الاجتماع المسلمون، من صياغة علم

$$
55 \text { 55 المرجع السابق، ص348. }
$$


اجتماع إسلامي. ونختم هذه القراءة بمقولة للدكتور إسماعيل راجي الفاروقي، يصف فيها

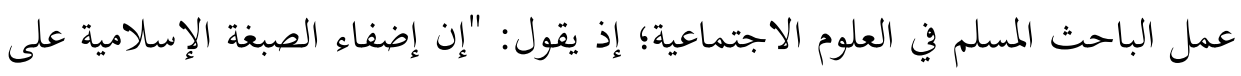

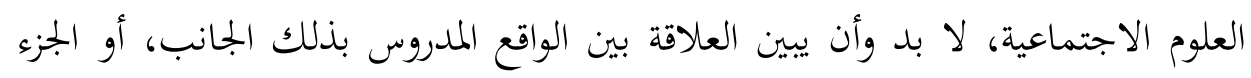

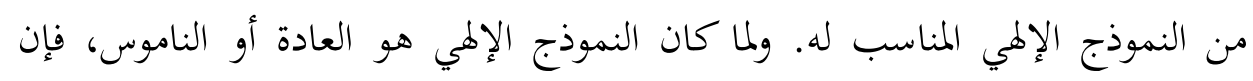

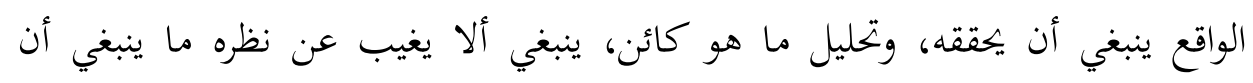

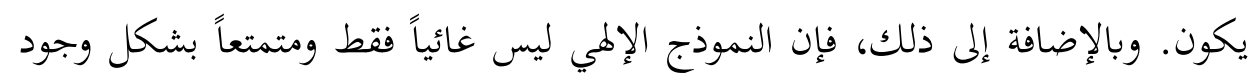

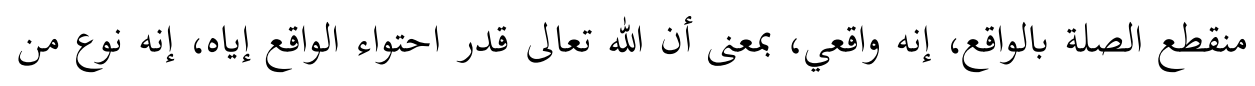

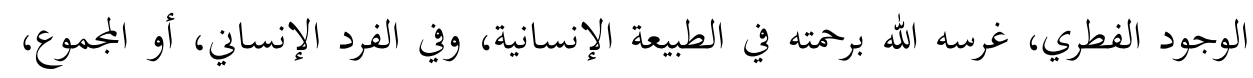

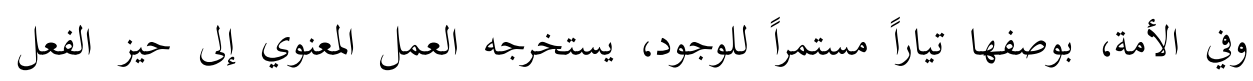

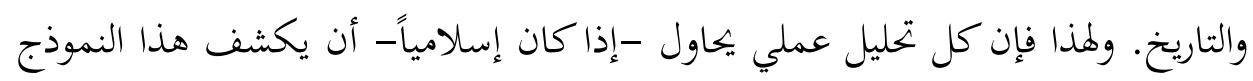

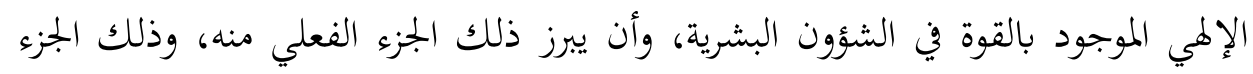
الموجود بالقوة، وأن يكشف عن عوامل تحقيق اكتمال عملية الاحتواء أو فاعليتها." وسعى المؤلف في الباب الرابع إلى تقديم تصور منهجي ينطلق من مقررات

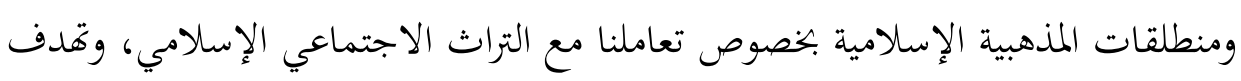

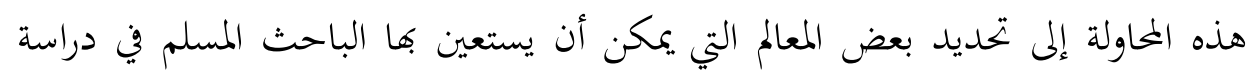

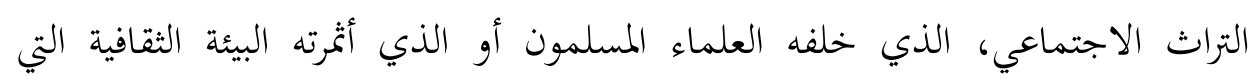
خلقت شروطها الحضارة الإسلامية.

بقي أن نتساءل عن طبيعة الجهود العلمية التي قام بها الباحثون في العالم الإسلامي

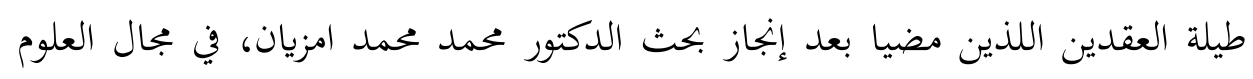

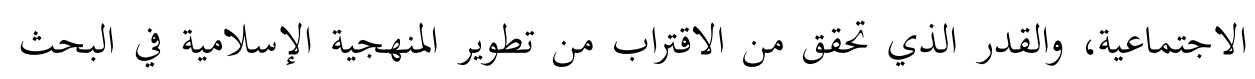

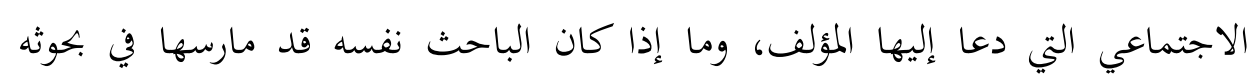

56 الفاروقي، إسماعيل راجي. العلوم الطبيعية والاجتماعية من وجهة النظر الإسلامية، ترجمة عبد الحميد الخربيي،

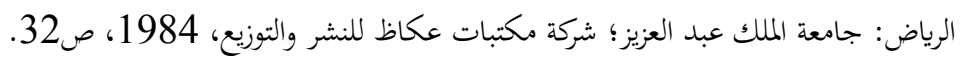


اللاحقة، وما إذا كانت هذه الدعوة قد وجدت آذاناً صاغية عند غيره من الباحثين. 